\title{
Matters of welfare and matters of law
}

\author{
Rob George \\ Faculty of Laws, University College London, UK
}

Key Words: adoption; contact; scope of welfare

The President of the Family Division knows a thing or two about both 'welfare' and 'law', but his judgment in $\operatorname{Re~B~(A~Child:~Post-Adoption~Contact)~[2019]~EWCA~Civ~} 29$ raises in passing some tricky questions about how the two concepts fit together.

\section{The decision in $\operatorname{Re} B$ :}

The child, whom I will call Beth, was born in April 2017. Her parents were disabled, in the mother's case significantly, with respect to their intellectual functioning, and concerns existed from the time of Beth's birth that, despite their best intentions, the parents might not be able to care for her safely and adequately. In September 2017, the local authority applied for care and placement orders, which were subsequently made. The local authority's care plan concluded that on-going contact between the parents and Beth would not be appropriate, and the trial judge made no order for any such contact, primarily on the basis of the Guardian's recommendation. However, at a later hearing in relation to the adoption application brought by the proposed adopters, the birth parents indicated a wish to have postadoption contact.

The power to order post-adoption contact is contained in s 51A of the Adoption and Children Act 2002 ('the ACA 2002'), introduced by way of the Children and Families Act 2014. That new provision, however, did not mark a fundamental change in the legal approach, since the court had been required to consider post-adoption since 2002, pursuant to s 46(6) of the ACA 2002. Amongst other effects, s 51A rationalised the legal framework, so that a previous split of jurisdiction between the ACA 2002 and the Children Act 1989 was abolished.

The main substantive effect of s 51A is contained in subsection (2):

(2) When making the adoption order or at any time afterwards, the court may make an order under this section-

(a) requiring the person in whose favour the adoption order is or has been made to allow the child to visit or stay with the person named in the order under this section, or for the person named in that order and the child otherwise to have contact with each other, or

(b) prohibiting the person named in the order under this section from having contact with the child.

When s 51A applies, it provides the exclusive power to make contact orders; the Children Act cannot be used (s 51A(8)), and the section applies where an adoption agency has placed, or is 
authorised to place, a child for adoption and the court is making or has made an adoption order (s 51A(1)).

In considering this provision in the Court of Appeal for the first time, Sir Andrew McFarlane $P$ reviewed the existing approach to post-adoption contact, which he described as 'well settled' (para 18). That position, in summary, is clearly expressed by Wall LJ in $R e R$ (Adoption: Contact) [2005] EWCA Civ 1128, para 49: 'The imposition on prospective adopters of orders for contact with which they are not in agreement is extremely, and remains extremely, unusual.'

That approach was challenged by the birth parents in this case, who argued that the new s 51A provisions marked a change in attitude to post-adoption contact. It was said that this change coincided with a shift in thinking based on research which increasingly favoured more 'open' adoption arrangements. As McFarlane P explained (para 59):

s 51A has been brought into force at a time when there is research and debate amongst social work and adoption professionals which may be moving towards the concept of greater 'openness' in terms of post-adoption contact arrangements, both between an adopted child and natural parents and, more particularly, between siblings

However, the President went on to say that the 'juxtaposition in timing' between the entry into force of s 51A and this recent research was more coincidental than intentional (para 59). Indeed, the inclusion within s 51A of the provision allowing the court specifically to forbid contact after adoption (see s $51 \mathrm{~A}(2)(\mathrm{b})$ ) 'was aimed at enhancing the position of adopters rather than the contrary (para 54). Consequently, the Court of Appeal considered that any changes in approach to post-adoption contact would be a matter to be led by social work practice in individual cases, rather than by guidance from the courts (para 60). But in explaining this view, McFarlane P said this (para 59):

any development or change from previous practice and expectations as to post-adoption contact that may arise from these current initiatives will be a matter that may be reflected in welfare decisions that are made by adopters, or by a court, on a case by case basis. These are matters of 'welfare' and not of 'law'.

\section{Discussion:}

It seems reasonably clear that the President's discussion about welfare and law in this context was intended to differentiate matters which were for the courts to determine and matters which were properly within the remit of social work practice and decisions for individual adopters. However, two issues arise in relation to that juxtaposition. The first is the choice of language, and the implication that matters of welfare are not matters of law. The second is the extent to which it is right for the court to disavow responsibility for contact and effectively delegate it to social workers and individual adopters. 
The difficulty with the differentiation of welfare and law is that great swathes of family and social welfare law are centred around exactly the concept of 'welfare'. When the LASPO cuts to legal aid were being considered, the government's consultation referred to much of the litigation in this area as 'unnecessary' because they were just about 'essentially personal matters' (MOJ 2010: paras 2.11 and 4.210). As John Eekelaar wrote at the time, this rhetoric implied that the government did not consider 'private matters' to involve questions of law or of justice at all; this approach 'deprive[s] legal rights of all effect' (Eekelaar, 2011: 313). The question of whether a family problem is recognised by the law, and what the law requires of the parties when it does, are both legal questions (Maclean and Eekelaar, 2019: 3). At the very least, therefore, questions of welfare are assessed in a legal framework; but I think it goes beyond that, and that matters of welfare, in this context, are matters of law.

Family law's primary aim, at least arguably, is 'to redress power imbalances and promote justice' (Maclean and Eekelaar, 2019: 26), but it generally does so in an individualised way based on broad concepts like 'welfare' and 'fairness'. These terms are inherently normatively vacuous, and so one of law's important functions is to 'provide standards' by which concepts like fairness or welfare are to be evaluated (Maclean and Eekelaar, 2019: 177-9). While I do not suggest that the passing comments in $\operatorname{Re} B$ are in any sense equivalent to the government's assault on family justice with LASPO, there is nonetheless a degree of concern that arises from the implication that 'welfare' might be outside the remit of 'law'.

The second issue is perhaps in part a consequence of the first. If matters to do with a child's welfare are not considered properly to be within the scope of 'law', and therefore of legal determination within the court structure where necessary, it facilitates the court's withdrawal from acceptance of responsibility for that issue. That this should be the approach in the context of post-adoption contact is in some ways a curiosity, since the law is clear that the court cannot deny a role in similar private law disputes. The court's responsibility for this issue is plainest in the wording of Practice Direction 12J (2017), which states that the court must decide whether proposed child arrangements 'accord with section 1(1) of the Children Act 1989', and must be scrutinised against that standard, whether a proposed order is made by agreement between the parties or otherwise.

So why should post-adoption contact be approached differently from any other contact dispute? The court's welfare jurisdiction is plainly engaged by s $51 \mathrm{~A}$. McFarlane LJ states in $\operatorname{Re} B$ (para 59) that ' $[\mathrm{t}]$ he law remains ... that it will only be in an extremely unusual case that a court will make an order stipulating contact arrangement[s] to which the adopters do not agree'. Section 51A itself gives no guidance as to the approach that the court should take, though it is fair to say that $\mathrm{s} 51 \mathrm{~A}(4)(\mathrm{c})$ imposes a requirement that a birth parent obtain the court's leave before an application can be made. The issue of leave aside, the substantive determination of an application under s 51A rests on the welfare principle (ACA 2002, s 1). Considered from a perspective of welfare and children's rights - both, in my view, matters of law - it is not immediately apparent that the court's approach should be so readily to defer to social workers and adoptive parents as $\operatorname{Re} B$, like the consistent authority before it, suggests. 


\section{References:}

Eekelaar, J. 2011. 'Not of the Highest Importance: Family Justice Under Threat'. Journal of Social Welfare and Family Law, 33: 311.

Maclean, M. and Eekelaar, J. 2019. After the Act: Access to Family Justice after LASPO. Oxford: Hart Publishing.

Ministry of Justice. 2010. Proposals for the Reform of Legal Aid in England and Wales. (Cm 7967). 